\title{
The Effect of Company and Auditor Characteristics on Timeliness of Financial Reporting: A Study of Banking Companies in Indonesia
}

\section{Finansal Raporlamanın Zamanlamasında Şirket ve Denetçi Özelliklerinin Etkisi: Endonezya'da Bankacılık Sektöründe Bir Çalışma}

\author{
Siswantoro Siswantoro ${ }^{1}$ (i) \\ ${ }^{1}$ Undergraduate Student, Universitas Negeri Semarang, Semarang, Indonesia. Eposta: siswantoro27@students.unnes.ac.id
}

ORCID: S.S. 0000-0003-0429-7895

\begin{abstract}
The purpose of this study is to find out the effect of company characteristics (profitability, company age, and company size) and auditor characteristics (quality of external auditors and audit committees) on the timeliness of financial reporting. The population in this study is all banking companies listed on the IDX 2017-2019, with a total of 90 samples. For data analysis, logistic regression analysis was performed with the analysis tool SPSS v.21. Each of the independent variables of the characteristics of the company and the auditors, namely, profitability and the audit committee, showed a significant effect, while the age of the company, size of the company, and quality of the external auditors had no significant effect. This research contributes to companies' future policies, especially in terms of improving the timeliness of financial reporting.

Keywords: Profitability, Company Age, Company Size, Quality of External Auditors, Audit Committee, Timeliness of Financial Reporting

öz

Bu çalışmanın amacı, şirket özelliklerinin (karlılık, şirket yaşı ve şirket büyüklüğü) ve denetçi özelliklerinin (dış denetçilerin ve denetim komitesinin kalitesi) finansal rapor sunumunun zamanında yapılmasının etkisini ortaya çıkarmaktır. Bu çalışmadaki popülasyon, IDX 2017-2019'da listelenen tüm bankacılık şirketleridir ve toplam örneklem sayısı 90'dır. Veri analizinde SPSS v.21 programı ile lojistik regresyon analizi kullanılmıştır. Finansal raporların zamanında sunulması üzerinde, şirket ve denetçi özelliklerinden kârlılık ve denetim komitesi önemli bir etkiye sahipken, şirketin yaşı, şirket büyüklüğü ve dış denetçilerin niteliği önemli bir etkiye sahip değildir. Bu araştırma, özellikle finansal rapor sunumunun zamanında yapılmasının iyileştirilmesi açısından şirketin gelecekteki politikalarına katkıda bulunur.
\end{abstract}

Anahtar kelimeler: Karlı1ık, Şirket Yaşı, Șirket Büyüklüğü, Dış Denetçilerin Kalitesi, Denetim Komitesi, Finansal Raporlamanın Zamanlılığı

Submitted/Başvuru: 24.12.2020 Revision Requested/Revizyon Talebi: 19.02.2021 Last Revision Received/Son Revizyon: 25.03.2021 Accepted/Kabul: 01.04.2021 Corresponding author/Sorumlu yazar: Siswantoro Siswantoro/ siswantoro27@students.unnes.ac.id

Citation/Atıf: Siswantoro S. (2021). The effect of company and auditor characteristics on timeliness of financial reporting: a study of banking companies in Indonesia. Muhasebe Enstitüsü Dergisi - Journal of Accounting Institute, 65, 59-73. https://doi.org/10.26650/MED.846176 


\section{Introduction}

In the midst of increasingly tight business competition, the timeliness of financial statement reporting by a company to the public is quite important and a concern for most companies. Financial statements that are reported in a timely manner to the public will reduce the occasional spread of misinformation and improve the quality of financial statements. Companies that submit financial statements outside the specified period of time tend to have a poor quality of financial information (Raesya \& Agusti, 2010).

Timeliness of financial statement reporting is also one of the main indicators in evaluating the quality of financial statements presented by the company (Putra \& Ramantha, 2015). It encourages many companies to keep their financial statements in accordance with the schedule.

The government has long implemented regulations on the maximum period of financial statement reporting by issuers listed on the Indonesia Stock Exchange (IDX). This regulation is contained in Law No. 85 of 1995 on Capital Markets. The Capital Market and Financial Institution Supervisory Board (Bapepam-LK) then lowers the regulation into the Attachment to the Decree of the Chairman of Bapepam Number: 80/PM/1996, which states that every company registered in the IDX must submit audited financial statements and annual reports on the IDX website no later than 120 days or 4 months from the end of the financial period. Bapepam-LK even tightened this rule by shortening the period of reporting of financial statements to only 90 days or 3 months starting after the end of the company period. In other words, the company is obliged to submit financial statements no later than March 31 each year. This is stated in Kep-17/PM/2002, which has been updated with Bapepam Regulation Number X.K.2, Attachment to The Decree of the Chairman of Bapepam Number: Kep-36/PM/2003 (Pradipta \& Suryono, 2017).

The timeliness of financial statement reporting is very important today, especially for corporate investors. Investors need timely reported financial information to consider quick and appropriate investment decisions in the future. The faster and better the quality of the company's financial statement reporting, the faster it will be for investors to make their next investment decision. Financial statements presented in a timely manner will also reduce the spread of misinformation to the public. Postponing the reporting of financial statements to the public will result in the reduction of relevant company documents, the increase of poor financial information, and uncertainty in investment decisions (Balakrishnan \& Ramachandran, 2016). Timely reporting of financial statements may be influenced by the company's characteristics, such as profitability, company size, and company age. Companies that have good characteristics, such as high profit earnings, large sizes, and older age, tend to be timelier in financial statement reporting. In addition to the characteristics of the company, the timeliness of financial statement reporting can also be affected by the quality of its auditor. Auditor characteristics, such as the quality of external auditors and the size of audit committees owned by the company, can be seen in the internal and external audits. These two auditor characteristics can encourage companies to be timelier in financial statement reporting. This is more due to the audit mechanism where, before the company publishes financial statements, it is required to go through a series of audit processes first. Companies with good audit characteristics tend to be faster in conducting audit processes that have an impact on the timely reporting of financial statements.

Previous studies examining factors that influence the timeliness of financial statement reporting in the dimensions of company characteristics and auditor characteristics have been widely conducted, but showed different results. According to Jusia \& Dewi (2012), Pradipta \& Suryono (2017), and Putra \& Ramantha (2015), profitability has a positive and significant influence on the timeliness of financial statements submitted by a company, but based on research from Budiyanto \& Aditya (2015), Irawan (2012), Kadir (2011), Rianti (2014), and Iyoha (2012), profitability level has no effect on the timeliness of the company's financial statements. Research conducted by Irawan (2012), Putra \& Ramantha (2015), and Iyoha (2012) found that a company's age influences the timeliness of financial statement reporting, but according to Kadir (2011), the company's age cannot influence the timeliness of the company's financial statement reporting. Hastutik (2015), Pradipta \& Suryono (2017), and Sartika (2014) found that a company's size was able to influence the company in timely financial statement reporting, but Budiyanto \& Aditya (2015), Jusia \& Dewi (2012), Irawan (2012), Kadir (2011), and Iyoha (2012) found that company size was not able to influence the timeliness of financial statement reporting. 
Based on Pradipta \& Suryono (2017) and Sartika (2014), the quality of external auditors may influence the timely reporting of financial statements, but based on research conducted by Budiyanto \& Aditya (2015) and Jusia \& Dewi (2012), timeliness of financial statements is not capable of being influenced by the quality of external auditors. Rivandi \& Gea (2018) found that the size of audit committees may influence the timely reporting of financial statements, but according to Putra \& Ramantha (2015) and Sartika (2014), the timeliness of the reporting of financial statements cannot be influenced by the audit committee.

Banking companies listed on the IDX are several of the companies that are famous for being timely in conveying financial information to outside parties. According to data processed from the IDX, in the period 2010-2012, $100 \%$ or all registered banking companies submitted their financial statements in a timely manner (Budiyanto \& Aditya, 2015). Based on this, banking companies listed on the IDX were selected as subjects in this study. This research is also motivated by the various results of previous research related to the timeliness of financial statement reporting based on the dimensions of company characteristics and auditor characteristics.

\section{Literature Review and Hypothesis Development}

\subsection{Grand Theory}

\section{Signaling Theory}

Signaling Theory, which was put forward by Spence (1973), provides an understanding that the company will be encouraged to convey signals in the form of financial statements to external parties. The encouragement of financial statement reporting is due to the asymmetry of information between the management, as the party that best understands the condition of the company, and the investors, as owners. This encourages management to convey signals in the form of financial statements to principals to reduce the information gap between the two parties.

The encouragement of financial statement reporting by the company can be done in a timely manner, but the company may decide to postpone it. This is due more to the good news or bad news received by the company. Companies that get good news tend to be timelier in financial statement reporting to investors compared to companies that get bad news. One reflection of the good news received by the company is drawn from the characteristics of the company. Companies with good business characteristics indicate that the company has received good news from the performance of its financial statements over a period of time. The characteristics of the company can be reflected through high profitability, the age of the company, and the size of the company described through the total assets.

Timely reporting of financial statements can also be driven by the characteristics of auditors owned by the company. Companies that have good auditor characteristics tend to be timelier in submitting financial statements to the public. This is because auditors are authorized to review the company's financial statements before they are made public. The characteristics of auditors in this study consist of two types, namely the quality of external auditors and the size of audit committees owned by the company.

\subsection{Hypothesis Development}

\section{The Effect of Profitability on the Timeliness of Financial Statement Reporting}

Companies that earn high profits are likely to report their financial statements in a timely manner. This is because the company wants to show investors that management has good business prospects (indicated by high returns) as quickly as possible, so that investors can quickly decide to invest in the company. Jusia \& Dewi (2012), Pradipta \& Suryono (2017), and Putra \& Ramantha (2015) found that timely financial statement reporting can be influenced by a high profitability level. The higher the level of profit earned, the more likely it is that the company is encouraged to submit its financial statements in a timely manner. But according to Budiyanto \& Aditya (2015), Irawan (2012), Kadir (2011), Rianti (2014), and Iyoha (2012), different results were shown. 
H1: Profitability has a significant effect on the timeliness of financial statement reporting

\section{The Effect of Company Age on the Timeliness of Financial Statement Reporting}

A company with a longer lifespan indicates that it has a longer experience in submitting financial statements to the public. This is because companies with a longer lifespan are already aware of the procedures and mechanisms for submitting the company's financial statements to the public, so they do not require much time to conduct the reporting process and provide greater opportunities for financial statements to be published in a timely manner.

This is supported by research conducted by Irawan (2012), Putra \& Ramantha (2015), and Iyoha (2012), which found that the age of the company can have a positive and significant effect on the reporting of financial statements. This indicates that the longer the life of the company, the more likely it is that the company will submit its financial statements to external parties in a timely manner. But the finding by Kadir (2011) stated that a company's age has no effect on the timeliness of financial statement reporting.

H2: Company age has a significant effect on the timeliness of financial statement reporting

\section{The Effect of Company Size on the Timeliness of Financial Statement Reporting}

Large total assets indicate that the company belongs to a large company. Large companies are likely to report their financial statements in a timely manner. This is because large companies tend to have worker resources and facilities that accommodate them, thus encouraging companies to submit their financial statements in a timely manner.

The research, which was conducted by Hastutik (2015), Pradipta \& Suryono (2017), and Sartika (2014), provides evidence that the size of a company has a positive and significant effect on the timeliness of the financial statement reporting. This indicates that the larger the size of a company, the timelier the company will tend to be in submitting its financial statements to the public. But according to Budiyanto \& Aditya (2015), Jusia \& Dewi (2012), Irawan (2012), Kadir (2011), and Iyoha (2012), company size has no effect on the timeliness of financial statements.

H3: Company size has a significant effect on the timeliness of financial statements

\section{The Effect of External Auditor Quality on the Timeliness of Financial Statement Reporting}

The quality of external auditors can be measured based on auditors incorporated in the Big Four Public Accounting Firms (KAP). Companies audited by external auditors incorporated in the KAP big four tend to be timelier in submitting their financial statements to the public. This is because the performance of KAP big four auditors in examining financial statements tends to be faster because of the high experience of auditing financial statements.

Pradipta \& Suryono (2017) and Sartika (2014) provide empirical evidence that the quality of auditors can influence the timeliness of financial statement reporting. The more qualified the external auditors owned by the company, the timelier the company tends to be in reporting financial statements. But different results were found in studies by Budiyanto \& Aditya (2015) and Jusia \& Dewi (2012).

H4: External auditor quality has a significant effect on the timeliness of financial statement reporting

\section{The Effect of Audit Committees on the Timeliness of Financial Statement Reporting}

The size of audit committees can determine whether the company can be timely in submitting its financial statements to investors or not. The more audit committees a company has, the faster it will be for companies to audit financial statements, which impacts the speed with which financial statements can be published to the public. This is inseparable from the duties of the audit committee, one of which is to assist the board of directors in auditing the company's financial statements internally before they are submitted to external auditors (Rivandi \& Gea, 2018). 
The research conducted by Rivandi \& Gea (2018) found that the higher the size of audit committees within the company, the more likely a company is faster in submitting financial statements to external parties. But the results are not in line with the research of Putra \& Ramantha (2015) and Sartika (2014).

H5: The audit committee has a significant effect on the timeliness of financial statement reporting.

\section{Research Framework}

\subsection{Research Type and Approach}

The type of research used in this study is quantitative research with a descriptive approach. Syahrum \& Salim (2012) and Putra (2015) said that quantitative research with a descriptive approach is a research method that aims to describe data in the form of numbers, which are then processed using analysis tools to produce findings. This research uses data in the form of figures that are sourced from the company's financial statements and then processed in a way that can later be described as a finding.

\subsection{Data Type and Sources}

The type of data used in this study is secondary data. Febriansyah (2017) provides an understanding that secondary data is data derived from sources obtained indirectly. The data source used in this research was obtained from the annual financial statements and accounting reports of banking companies that have been audited and were downloaded from the official website of IDX (www.idx.co.id).

\subsection{Population, Sampling Technique and Sample Size}

All banking companies listed on the IDX were selected as research populations. The selected research period was three years (2017 to 2019). The sampling technique in this study used purposive sampling. This is in accordance with the statement by Sugiyono (2016), which states that the characteristics of purposive sampling technique rest in the way researchers take samples based on predetermined criteria. The criteria for the population that was sampled in this study are as follows:

1. Banking companies were registered in IDX from 2017 to 2019.

2. Banking companies publish audited annual financial statements and accounting reports on the IDX website during the research period of 2017 to 2019.

3. The financial statements of banking companies contain all the data needed in the research.

The sample selection process was carried out using the above criteria. Only 30 out of 45 companies met the criteria, so the total sample in this study was only 30 companies. The number of samples was then multiplied by the period of research (3 years (2017-2019)), so the number of units of analysis obtained in this study was 90 units.

\subsection{Variable Operational Definition}

\subsubsection{Dependent Variable}

\section{Timeliness of Financial Reporting}

Based on the latest regulation published by Bapepam-LK, which refers to the Attachment to the Decree of the Chairman of Bapepam Number: Kep-36/PM/2003, companies registered with the IDX are declared on time in submitting financial statements when reporting their financial statements on the IDX website no later than 90 days or 3 months from the end of the company's financial period. Another sentence states that the company is obliged to report its financial statements on or before March 31 each year. If the company publishes financial statements outside of that time period, it will be declared late by Bapepam-LK. However, due to the Covid-19 Pandemic that occurred in early 2020, the IDX finally issued a Decree of the Board of Directors of PT Bursa Efek Indonesia Number Kep-00027/Bei/03-2020 concerning the Relaxation of Deadline 
for Reporting of Financial Statements and Annual Report (issued on March 20,2020). The letter extended the deadline for submitting 2019 annual financial statements from March 31 to May 31, 2020. Based on that, the dependent variable measurement in this study uses dummy variables, where banking companies were given a score of 1 for reporting their financial statements on or before March 31, 2017 and 2018, and 0 when reporting after March 31, 2017 and 2018. Due to the extension of the financial statement reporting period to May 31, 2020, the banking company was given a score of 1 if it submitted its annual financial statements for the 2019 period before May 31, 2020 and 0 if it submitted its annual financial statements beyond the extension date of May 31, 2020.

\subsubsection{Independent Variable}

\section{a. Profitability}

Profitability is often used by management as an ideal measure to assess a company's performance (Budiyanto, 2015). Profitability is a ratio that measures the level of profit earned by a company when compared to the amount of assets or capital owned (Putra \& Ramantha, 2015). The high profitability obtained by a company will bring fresh wind or good news for the company, thus spurring management to immediately report its financial statements in a timely manner to investors. Measurement of profitability in this study was performed using Return on Assets (ROA) with the following formula:

ROA $=$ Net Income $/$ Total Assets

\section{b. Company Age}

The ideal age of the company should be calculated based on the date of establishment of the company. Referring to research by Putra \& Ramantha (2015), it can also be calculated from the date of registration of the company on the IDX until the research period. The longer the life of the company, the timelier the company should be in submitting its financial statements to the public. This is inseparable from the experience of submitting financial statements obtained compared to newly established companies. The company's age measurement in this study refers to the research (Putra \& Ramantha, 2015).

\section{c. Company Size}

Hastutik (2015) defines the size of a company as the total amount of all assets owned by the company. The size of the company is predicted to affect the company's policy in submitting financial statements in a timely manner. This is because companies with large sizes usually have employee resources and supporting facilities so that financial statements can be published in a timely manner on the IDX website. In addition, large companies usually come under pressure from outside parties, such as investors, to submit financial statements in a timely manner. Company size was provided by the following formula:

Company Size (SIZE) $=$ Log (Total Assets).

\section{d. External Auditor Quality}

External quality indicators of auditors are often measured with the size of the Public Accounting Firm (KAP). The larger the size of KAP, the more qualified the auditor is. A KAP's large size indicates that it has competent auditor resources so that it can complete the audit process of financial statements more quickly and efficiently, which has an impact on the speed with which financial statements can be published to the public (Pradipta \& Suryono, 2017). The KAP that is internationally recognized as having the best reputation is part of the big four group (Jusia \& Dewi, 2012). Measurement of the external quality of auditors owned by banking companies in this study was performed using dummy variables, where banking companies were given a score of 1 if audited by KAP and 0 if not audited by KAP. 


\section{e. Audit Committee}

Rivandi \& Gea (2018) define the audit committee as a group of members of the company's board of directors, who are responsible for establishing good relationships with external or independent auditors, including assisting external auditors in auditing the company's financial statements. The audit committee within the company consists mostly of three to five people and does not belong to the management group (Arens, Elder, \& Beasley, 2010). The greater the size of audit committees, the faster companies will be able to audit financial statements, which in turn has an impact on the timely reporting of financial statements. The measurement of the audit committee in this research was based on the quantity or size of audit committees owned by the company.

Audit Committee (KA) = Size of audit committees

\section{Data Analysis Methods}

The data analysis method used in this study was logistic regression analysis using the SPSS version 21 analysis tool. Logistic regression analysis was chosen because the dependent variables are dummy variables that are categorized as non-metric data (categories), while the independent variables are a combination of continuous variables and categories. Harlan (2013) stated that logistics regression analysis is used to test whether free variables can predict the amount of influence on bound variables. Logistic regression analysis also does not require a normality test on the free variables used (Ghozali, 2011). Gujarati \& Porter (2003) also added that logistic regression does not require homocedasticity on independent variables, or in other words, it ignores hesterocedasticity, so the stages in this research are only two steps, namely descriptive statistical analysis and hypothesis testing.

\section{Findings}

\subsection{Descriptive Statistical Analysis}

The results of descriptive statistical analysis for the dependent variables show there are 11 data (12.22\%) samples consisting of 4 data in 2017, 5 data in 2018, and 2 data in the period 2019 that submitted untimely financial statements during the 20172019 timeframe, while the remainder submitted their financial statements in accordance with the specified time. The percentage correct column in the table above shows that $87.8 \%$ of variables were able to predict the timeliness of financial statement reporting of banking companies.

Profitability has a minimum value of $-6.4 \%$ which means that there were banking companies that suffered losses of $6.4 \%$, while the highest profit gain during the research period was $3.9 \%$, with an average ROA rate of $0.7 \%$ during the period 20172019. The youngest age of a banking company was one year, the oldest age recorded during the period 2017-2019 was 30 years, and the average age was 14.2 years. The smallest value of the company's size was recorded at 5.25 , with the largest value being 9.15 and the average size of the listed company being 7.34. In the period 2017-2019, most banking companies were audited by auditors from the Public Accounting Office of the Big Four, but others were audited by other KAP outside the KAP big four. The smallest recorded size of audit committees was 3 people, with the highest number reaching 7 people and the average being 3-4 people.

\subsection{Regression Model Feasibility Test}

Before being used in the study, the previous regression model had to go through a feasibility test first. In logistic regression analysis, the feasibility test model used hosmer table and lemeshow test, where if the significance value of $>0.05$ was obtained then the regression model could be said to be feasible to use.

The chi-square on the hosmer and lemeshow test table shows the number 11.474 with a significance of $0.176>0.05$. This indicates that the regression model is fit and could be carried out in the next regression analysis process. 


\subsection{Overall Model Fit}

The overall test of regression model or overall model fit in this study was to look at the value of -2 log likelihood before and after independent variables were inserted into the regression model. When independent variables were inserted into the regression model, the value of $-2 \log$ likelihood got smaller or decreased, and then it could be said that the variable improved the regression model to be used, or in other words, the model was worth using.

The value of $-2 \log$ likelihood before an independent variable was entered ranged from 66.839 to 69.136 , while when an independent variable was entered the value of $-2 \log$ likelihood showed a decrease to a range from 54.8894 to 61.827. This suggests that independent variables can improve the overall regression model used in the study, so it can be said that the entire regression model in this study is feasible.

\subsection{Determination Coefficient Test}

The coefficient of determination aims to find out how much percentage of independent variables affect dependent variables, or in other words, this test was conducted to find out how large free variables were able to explain bound variables. In the logistic regression test, the coefficient of determination test was carried out by looking at the value of nagelkerke $r$ square.

The value of nagelkerke $r$ square showed a percentage of $23.7 \%$ with a value of $-2 \log$ likelihood of 54.894. The five free variables used in this study were profitability, company age, company size, quality of external auditors, and audit committee. These five variables were only able to explain $23.7 \%$ of the variable timeliness of financial statements submitted to banking companies, while the remaining $76.3 \%$ was explained by other variables.

\subsection{Simultaneous Test}

This test was conducted to find out if the five independent variables, when tested together, would have a significant effect on the dependent variables or not. To know this is to look at the significance value in the table omnibus test of model coefficients where, if the value of significance is $<0.05$, then all independent variables simultaneously have a significant effect on the bound variable.

The significance value in the omnibus test table of coefficient models with chi-square (11.945) was $0.036(<0.05)$. In accordance with the basis of decision-making, when the five independent variables are tested together, it shows a significant influence on the variable timeliness of financial statement reporting.

\subsection{Partial Test}

In contrast to the simultaneous tests, the partial tests emphasize independent variable testing of dependent variables if performed partially or separately. The partial test results are shown in the table as follows:

Partial tests can also be used to see which regression model equation should be used. By looking at the value B in the table of variables in the equation, the regression model equation was obtained as follows:

Descriptions:

$$
\begin{aligned}
& \mathrm{Y}=\text { Timeliness of Financial Reporting } \\
& \mathrm{X} 1 \text { = Profitability } \\
& \mathrm{X} 2 \text { = Company Age } \\
& \mathrm{X} 3 \text { = Company Size } \\
& \mathrm{X} 4=\text { External Auditor Quality } \\
& \mathrm{X} 5=\text { Audit Committee } \\
& \mathrm{E}=\text { Error }
\end{aligned}
$$


From the equation of the regression model that was formed, it can be seen that if all independent variables are 0 and the error value is ignored, then the variable on time of financial statement reporting is worth 3.843. Put another way, banking companies could still be timely in submitting their financial statements to the public even though the five independent variables used in the study were worth 0 or none.

In logistic regression analysis, this partial test is done by looking at the significance value in the variable table in the equation, where if the value of significance is $<0.05$ then the independent variable has a significant effect on the bound variable.

\section{Discussion}

\subsection{The Effect of Profitability on the Timeliness of Financial Statement Reporting}

The partial test indicates that the significance value of the profitability variable in the variable table in the equation was $0.040(<0.05)$. This indicates that profitability has an effect on the timeliness of financial statement reporting of banking companies, so that the first hypothesis is accepted. The effect of variable profitability on the timeliness of the financial statement reporting indicates a positive direction indicated by a value of $\mathrm{B}$ of 40.427 . This indicates that if the profitability of the banking company is worth 1 , then the timeliness of banking financial statement reporting is financial statement reporting positive value of 40.427 . The higher the profitability obtained by banking companies, the timelier the company will be in publishing its financial statements to the public. A high profit is one of the good pieces of news received by companies from performance carried out during one period. Banking companies certainly do not want a delay in submitting their financial statements to the public if the company earns a high profit. The high profit earned by a company will encourage investors to invest more quickly in the company. The timelier the company is in publishing its business performance to the public, including investors, the faster investors will be able to make investment decisions about the company.

This result is in line with previous research conducted by Jusia \& Dewi (2012), Pradipta \& Suryono (2017), and Putra \& Ramantha (2015), who agreed that profitability can influence the timeliness of a company's financial statements. However, the results of this study are contrary to the findings of Budiyanto \& Aditya (2015), Irawan (2012), Kadir (2011), Rianti (2014), and Iyoha (2012) who said that profitability has no effect on the timeliness of a company's financial statements.

\subsection{The Effect of Company Age on the Timeliness of Financial Statement Reporting}

The significance of the company's age variable in this study showed a figure of $0.130(>0.05)$. This means that the company's age was not able to influence the timeliness of the reporting of financial statements to the public, so the second hypothesis was rejected.

In this study, the length of the company's lifespan could not be used as a reference that a company can submit its financial statements to the public in a timely way. In other words, companies with relatively longer lifespans were not necessarily able to submit their financial statements in a timely manner, and younger companies are also not sure to be late in submitting the financial reports to the public. This is because a banking company registered in the IDX is a competitive and selective company for both newly registered and long-term registered companies. Before being registered with IDX, banking companies must pass a strict selection process and meet the criteria by having good resources in order to compete. These good resources will encourage banking companies to be timelier in delivering financial statements to the public.

This result is in line with previous research conducted by Kadir (2011) that stated the age of the company has no effect on the timeliness of the reporting of financial statements. These findings reject previous research conducted by Irawan (2012), Putra \& Ramantha (2015), and Iyoha (2012), which simultaneously say that the age of a company influences the timeliness of financial statement reporting. 


\subsection{The Effect of Company Size on the Timeliness of Financial Statement Reporting}

The partial test on company size variables indicated that the significance value was $0.412(>0.05)$. It indicates that the company's variable size had no effect on the timeliness of the delivery of financial statements of banking companies, so the third hypothesis is completely rejected. The size of the company that is measured with the total assets owned by the company is not merely a guarantee that the company will be on time in submitting its financial statements to the public. This is because the larger the company, the more financial information enters the company. This increases the amount of complex financial information that must be managed by the company. With increasingly complex financial information that must be managed by management, there is a greater chance that the company will be late or untimely in delivering its financial statements to the public.

The results of this study agreed with previous findings made from research by Budiyanto \& Aditya (2015), Jusia \& Dewi (2012), Irawan (2012), Kadir (2011), and Iyoha (2012), which simultaneously stated that the size of the company is not able to affect the timeliness of the company's financial statements. The results of this study rejected previous findings from the studies by Hastutik (2015), Pradipta \& Suryono (2017), and Sartika (2014), which actually argued otherwise.

\subsection{The Effect of External Auditor Quality on the Timeliness of Financial Statement Reporting}

The partial test results on external quality variable auditors in this study showed a significance value of $0.316(>0.05)$, which means that the quality of external auditors had no effect on the timeliness of the company's financial statement reporting, so it can be ascertained that the fourth hypothesis was rejected. The quality of external auditors indicated by the size of the public accounting firm was not able to influence the timeliness of financial statement reporting. This means that banking companies audited by KAP affiliated with the KAP big four have not been confirmed to deliver their financial statements in a timely manner and vice versa.

This is because the process of preparing financial statements is mostly done by the company or management. The performance of KAP in auditing the company's financial statements will be greatly influenced by the performance of management in producing financial reports. In other words, whether the company is timely or not in submitting financial reports still depends on the performance of these managers. Even though the company is audited by one of the big four KAPs, the manager may be late in submitting its financial reports, so in the end this will not guarantee that a company submits its financial reports in a timely manner.

The results of this study are in line with the findings of Budiyanto \& Aditya (2015) and Jusia \& Dewi (2012), which stated that the quality of external auditors has no effect on the timeliness of a company's financial statements, but rejects previous findings from research conducted by Pradipta \& Suryono (2017) and Sartika (2014).

\subsection{The Effect of Audit Committee on the Timeliness of Financial Statement Reporting}

The significance of the audit committee variables shows a figure of $0.012(<0.05)$ with a B value of -0.946 . These results indicate that the audit committee influenced the timeliness of the financial statement reporting of banking companies so that the final hypothesis was accepted. The direction of the audit committee's variable influence indicates a negative value, which means that the fewer audit committees the company has, the more timely the company will be in submitting its financial statements to the public.

The audit committee is a group of competent people appointed by the board of directors, one of their duties being to assist the company in auditing financial statements. The audit committee is also required to improve the quality of the company's financial reporting, so that with the audit committee, the company will be faster in drafting, auditing, and reporting financial statements to the public. In this research, banking companies with a small size of audit committee members were able to encourage the timeliness of financial statement reporting. This is due to the high quality and competence of the audit committee in banking companies, so that although the size of audit committees of a company was relatively small, it had a quality audit competence that would still encourage the timeliness of financial statement reporting to the public. 
The results of this study are in line with research by Rivandi \& Gea (2018), which said that the size of audit committees is able to influence the timeliness of the reporting of financial statements, but these findings reject previous research conducted by Putra \& Ramantha (2015) and Sartika (2014).

\section{Conclusion}

This study concluded that one variable of each characteristic of a company and auditor was able to influence the timeliness of financial statement reporting. In this study, profitability and audit committees have a significant effect on the timeliness of financial statement reporting of banking companies, while the other three variables, namely the company's age, company's size, and the quality of external auditors, had no effect on the timeliness of financial statement reporting. The study also concluded only $23.7 \%$ of all free variables were able to explain dependent variables.

Hakem Değerlendirmesi: Dış bağımsız.

Çıkar Çatışması: Yazar çıkar çatışması bildirmemiştir.

Etik Komite Onayı: Bu çalışma için etik komite onayı alınmışıır.

Finansal Destek: Yazar bu çalışma için finansal destek almadığını beyan etmiştir.

Peer-review: Externally peer-reviewed.

Conflict of Interest: The author has no conflict of interest to declare.

Ethics Committee Approval: This study was approved by the Ethical Committee.

Grant Support: The author declared that this study has received no financial support.

\section{References}

Arens, A. A., Elder, R. J., \& Beasley, M. S. (2010). Auditing dan Jasa Assurance. Pendekatan Terintegrasi (edisi 13). Jakarta: Erlangga

Balakrishnan, C., \& Ramachandran, M. K. (2016). Corporate Governance and Timeliness of Financial Corporate Governance and Timeliness of Financial. SSRN Electronic Journal. https://doi.org/http://dx.doi.org/10.2139/ssrn.2888519

Budiyanto, S., \& Aditya, E. M. (2015). Faktor-Faktor Yang Memengaruhi Ketepatan Waktu Pelaporan Keuangan: Studi Empiris Perusahaan Food and Beverages Periode 2010-2012. Fokus Ekonomi, 10(1), 77-87. https://ejournal.stiepena.ac.id/index.php/fe/article/ view/74

Departemen Keuangan Republik Indonesia Badan Pengawas Pasar Modal Salinan Keputusan Ketua Badan Pengawas Pasar Modal Nomor: Kep-17/Pm/2002 Tentang Kewajiban Penyampaian Laporan Keuangan Berkala Ketua Badan Pengawas Pasar Modal

Febriansyah, A. (2017). Tinjauan Atas Proses Penyusunan Laporan Keuangan Pada Young Enterpreneur Academy Indonesia Bandung. Jurnal Riset Akuntansi, 8(2). https://doi.org/10.34010/jra.v8i2.525

Ghozali, Imam. (2011). Aplikasi Analisis Multivariate dengan Program IBM SPSS 19. Semarang: Badan Penerbit Universitas Diponegoro. Gujarati, D. N., \& Porter, D. C. (2003). Basic econometrics (4th, international ed.)

Harlan, J. (2013). Analisis Regresi Logistik. In Journal of Chemical Information and Modeling (Vol. 53, Issue 9).

Hastutik, S. (2015). Pengaruh Profitabilitas, Likuiditas, Struktur Kepemilikan, Ukuran Perusahaan dan Opini Audit Terhadap Ketepatan Waktu Pelaporan Keuangan Perusahaan. Jurnal Akuntansi dan Sistem Teknologi Informasi, 1(Khusus), 102-111. http://ejurnal.unisri. ac.id/index.php/Akuntansi/article/view/1054

Irawan, E. A. (2012). Faktor-Faktor yang Mempengaruhi Ketepatan Waktu Pelaporan Keuangan Perusahaan Perbankan Go Publik di Bursa Efek Indonesia. In Skripsi: Universitas Negeri Semarang: Vol. Semarang.

Iyoha, F. O. (2012). Company Attributes and the Timeliness of. Sayco Secured Assets Yield Corporation Investment Banking, 1(3), 41-49.

Jusia, I \& Dewi. (2012). Faktor-Faktor Yang Mempengaruhi Ketepatan Waktu Penyampaian Laporan Keuangan Pada Perusahaan Real Estate dan Property Yang Terdaftar Di Bursa Efek Indonesia Diajukan. XVII(03), 368-384.

Keputusan Ketua Badan Pengawas Pasar Modal Nomor: Kep-36/PM/2003 Tentang Kewajiban Penyampaian Laporan Keuangan Berkala 
Pradipta, D. N., \& Suryono, B. (2017). Analisis Faktor-Faktor Yang Mempengaruhi Ketepatan Waktu. Jurnal Ilmu Dan Riset Akuntansi, 6, 1-17.

Putra, E. A. (2015). Anak Berkesulitan Belajar di Sekolah Dasar Se-Kelurahan Kalumbuk Padang. Jurnal Ilmiah Pendidikan Khusus, 1(3), 71-76. http://103.216.87.80/index.php/jupekhu/article/viewFile/6065/4707

Putra, I. G. A. P., \& Ramantha, I. W. (2015). Pengaruh Profitabilitas, Umur Perusahaan, Kepemilikan Institusional, Komisaris Independen, Dan Komite Audit Pada Ketepatwaktuan Publikasi Laporan Keuangan Tahunan. E-Jurnal Akuntansi Universitas Udayana, 10(1), 199-213.

Raesya, L., \& Agusti, R. (2010). Analisis Faktor-Faktor yang Mempengaruhi Ketepatan Waktu Penyampaian Laporan Keuangan ke Publik pada Perusahaan yang Terdaftar DIBEI (2005-2007). Jurnal Ekonomi Universitas Riau, 18(02), 8793.

Rianti, R. (2014). Pengaruh Profitabilitas, Leverage, Kepemilikan Institusional, dan Kepemilikan Manajerial Terhadap Ketepatan Waktu Pelaporan Keuangan. E-Journal S1 Ak Universitas Pendidikan Ganesha, 02(1), 1-24.

Rivandi, M., \& Gea, M. M. (2018). Pengaruh Mekanisme Corporate Governance Terhadap Ketepatan Waktu Pelaporan Keuangan (Studi Empiris Pada Perusahaan Perbankan Milik Pemerintah Pusat). Jurnal Akuntansi dan Pajak, 19(1), 1. https://doi.org/10.29040/jap. v19i1.167

Sartika, R. (2014). Pengaruh Peran Komite Audit, Reputasi Kap dan Ukuran Perusahaan Terhadap Ketepatan Waktu Penyampaian Laporan Audit (Studi Empiris Pada Perusahaan Perbankan dan Perusahaan Asuransi yang Terdaftar di BEI) Artikel.

Spence, Michael. (1973). Job Market Signaling. The Quarterly Journal of Economics, 87,( 3) (Aug., 1973), pp. 355-374. The MIT Press. Surat Keputusan Direksi PT Bursa Efek Indonesia. (2020). Relaksasi Batas Waktu Penyampaian Laporan Keuangan dan Laporan Tahunan. Jakarta: Republik Indonesia.

Undang-Undang Nomor 85 Tahun 1995 tentang Pasar Modal. (1995). Jakarta: Republik Indonesia. 


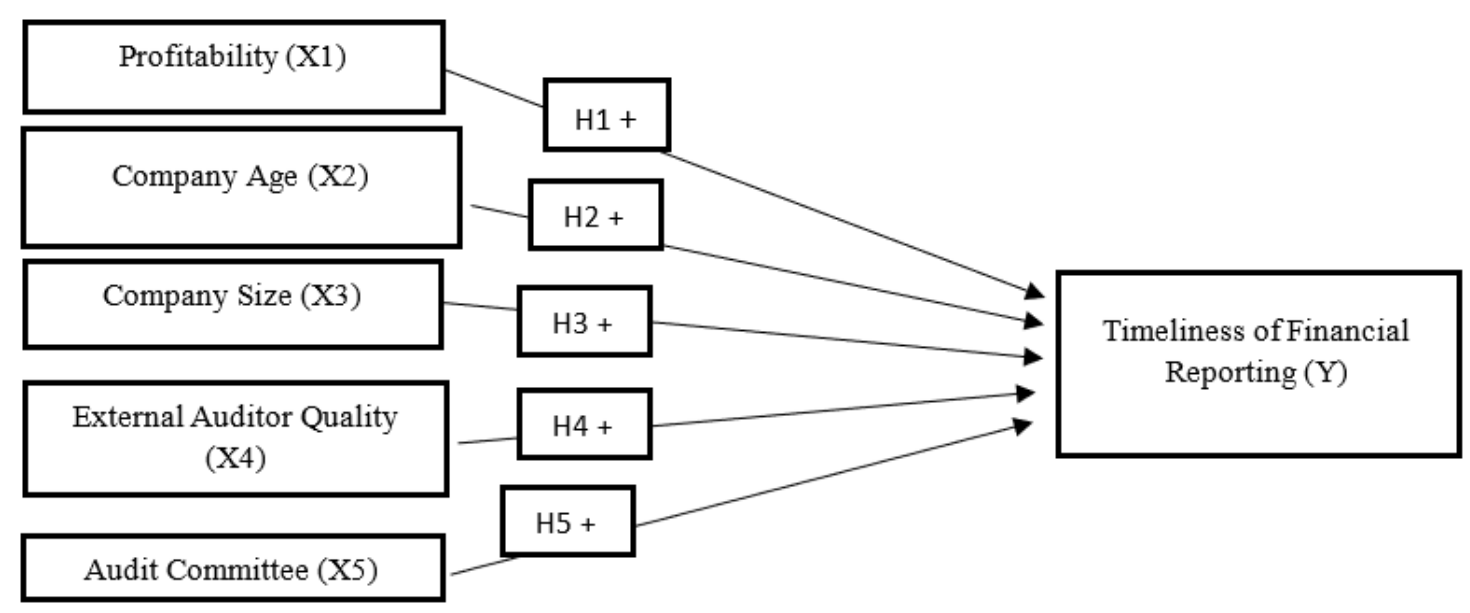

Figure 1: Research Framework

Source: Researcher, 2020

Table 1. Descriptive Statistical Analysis of Dependent Variables

Classification Table ${ }^{a, b}$

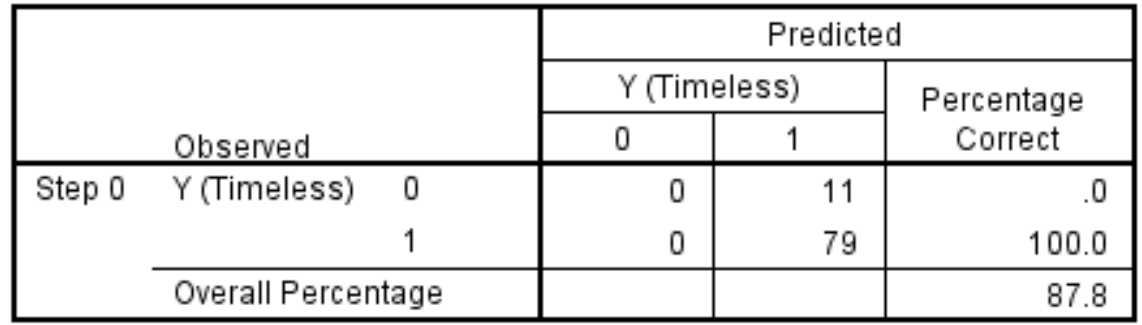

a. Constant is included in the model.

b. The cut value is .500

Source: Secondary Data Processed, 2020

Table 2. Descriptive Statistical Analysis of Independent Variables

\section{Descriptive Statistics}

\begin{tabular}{|l|r|r|r|r|r|}
\hline & N & Minimum & Maximum & Mean & Std. Deviation \\
\hline X1 (Profit) & 90 & -.06400 & .03900 & .0071147 & .01673914 \\
X2 (Age) & 90 & 1 & 30 & 14.20 & 7.873 \\
X3 (Size) & 90 & 5.25 & 9.15 & 7.3455 & .89236 \\
X4 (Quality Auditor) & 90 & 0 & 1 & .58 & .497 \\
X5 (Komite Audit) & 90 & 3 & 7 & 3.87 & 1.182 \\
Valid N (listwise) & 90 & & & & \\
\hline
\end{tabular}

Source: Secondary Data Processed, 2020 
Table 3. Hosmer and lemeshow test

Hosmer and Lemeshow Test

\begin{tabular}{|l|r|r|r|}
\hline Step & Chi-square & \multicolumn{1}{c|}{ df } & Sig. \\
\hline 1 & 11.474 & 8 & .176 \\
\hline
\end{tabular}

Source: Secondary Data Processed, 2020

Table 4. Overall Model Fit Before Independent Variable Inserted

Iteration History ${ }^{a, b, c}$

\begin{tabular}{|cr|r|r|}
\hline \multicolumn{2}{|c|}{} & \multirow{2}{*}{$\begin{array}{c}\text {-2 Log } \\
\text { Iteration }\end{array}$} & Coefficients \\
\cline { 4 - 4 } & & likelihood & Constant \\
\hline Step 0 & 1 & 69.136 & 1.511 \\
& 2 & 66.881 & 1.906 \\
3 & 66.839 & 1.970 \\
4 & 66.839 & 1.972 \\
5 & 66.839 & 1.972 \\
\hline
\end{tabular}
a. Constant is included in the model.
b. Initial-2 Log Likelihood: 66.839
c. Estimation terminated at iteration number 5 because parameter estimates changed by less than .001 .

Source: Secondary Data Processed, 2020

Table 5. Overall Model Fit After Independent Variable Inserted

Iteration History ${ }^{a, b, c, d}$

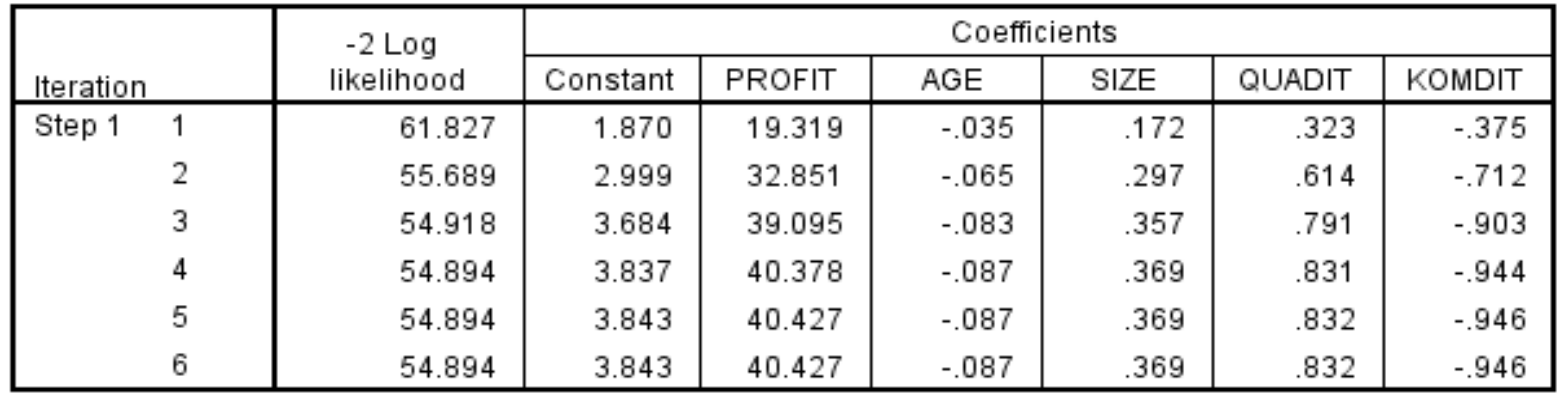
a. Method: Enter
b. Constant is included in the model.
c. Initial -2 Log Likelihood: 66.839 d. Estimation terminated at iteration number 6 because parameter estimates changed by less than .
001 .

Source: Secondary Data Processed, 2020

Table 6. Determination Coefficient Test

\section{Model Summary}

\begin{tabular}{|l|c|c|c|}
\hline Step & $\begin{array}{c}-2 \text { Log } \\
\text { likelihood }\end{array}$ & $\begin{array}{c}\text { Cox \& Snell R } \\
\text { Square }\end{array}$ & $\begin{array}{c}\text { Nagelkerke R } \\
\text { Square }\end{array}$ \\
\hline 1 & $54.894^{\mathrm{a}}$ & .124 & .237 \\
\hline
\end{tabular}

a. Estimation terminated at iteration number 6 because parameter estimates changed by less than .001

Source: Secondary Data Processed, 2020 
Table 7. Omnibus Test of Model Coefficients

Omnibus Tests of Model Coefficients

\begin{tabular}{|rl|r|r|r|}
\hline & & Chi-square & \multicolumn{1}{c|}{ df } & \multicolumn{1}{c|}{ Sig. } \\
\hline Step 1 & Step & 11.945 & 5 & .036 \\
& Block & 11.945 & 5 & .036 \\
& Model & 11.945 & 5 & .036 \\
\hline
\end{tabular}

Source: Secondary Data Processed, 2020

Table 8. Variables in the equation

Variables in the Equation

\begin{tabular}{|c|c|c|c|c|c|c|c|c|c|}
\hline & & \multirow[b]{2}{*}{ B } & \multirow[b]{2}{*}{ S.E. } & \multirow[b]{2}{*}{ Wald } & \multirow[b]{2}{*}{ df } & \multirow[b]{2}{*}{ Sig. } & \multirow[b]{2}{*}{$\operatorname{Exp}(B)$} & \multicolumn{2}{|c|}{$95 \%$ C.I.for EXP(B) } \\
\hline & & & & & & & & Lower & Upper \\
\hline \multirow[t]{6}{*}{ Step $1^{\mathrm{a}}$} & PROFIT & 40.427 & 19.653 & 4.231 & 1 & .040 & $3.607 E+17$ & 6.736 & $1.931 E+34$ \\
\hline & AGE & -.087 & .057 & 2.293 & 1 & .130 & .917 & .820 & 1.026 \\
\hline & SIZE & .369 & .450 & .673 & 1 & .412 & 1.447 & .599 & 3.497 \\
\hline & QUADIT & .832 & .830 & 1.004 & 1 & .316 & 2.298 & .451 & 11.702 \\
\hline & KOMDIT & -.946 & .377 & 6.295 & 1 & .012 & .388 & .185 & .813 \\
\hline & Constant & 3.843 & 3.167 & 1.473 & 1 & .225 & 46.660 & & \\
\hline
\end{tabular}

a. Variable(s) entered on step 1: PROFIT, AGE, SIZE, QUADIT, KOMDIT.

Source: Secondary Data Processed, 2020 
